\title{
Marcin Olszewski
}

Uniwersytet Ekonomiczny w Poznaniu

e-mail: marcin.olszewski@ue.poznan.pl

\section{Barbara Kowalczyk}

Ośrodek Przetwarzania Informacji - Państwowy Instytut Badawczy

e-mail: bkowalczyk@opi.org.pl

\section{ZRÓŻNICOWANIE INNOWACYJNOŚCI PRZEDSIECBIORSTW HOTELARSKICH W POLSCE - STUDIUM EMPIRYCZNE}

\section{THE DIFFERENTIATION OF INNOVATION ACTIVITY IN THE POLISH HOTEL INDUSTRY - THE EMPIRICAL STUDY}

DOI:10.15611/pn.2017.473.36

JEL Classification: O31, Z31

Streszczenie: Konkurencyjność przedsiębiorstw turystycznych uwarunkowana jest w dużym stopniu ich zdolnością do tworzenia innowacji. Celem artykułu jest identyfikacja poziomu innowacyjności przedsiębiorstw hotelarskich w Polsce oraz jego zróżnicowania. W pierwszej części artykułu przedstawiono przegląd badań poświęconych zróżnicowaniu poziomu innowacyjności w przedsiębiorstwach hotelarskich. Druga część przybliża metodykę badania empirycznego zrealizowanego w 2015 r. wśród 400 przedsiębiorstw hotelarskich w Polsce. W części trzeciej zaprezentowane zostały wyniki badania empirycznego. $\mathrm{Z}$ badania wynika, że poziom innowacyjności w statystycznie istotny sposób różnicują dwie cechy: wielkość hotelu i przynależność do międzynarodowej sieci hotelowej.

Słowa kluczowe: innowacje, przedsiębiorstwa hotelarskie, determinanty innowacyjności.

Summary: The competitiveness of tourism enterprise largely depends on its ability to create innovations. This empirical article presents the results of the quantitative study carried out in 400 Polish hotels. The aim of this article is to identify the level of innovation activity in hotel companies in Poland and its differentiation in terms of size, standard and affiliation to a hotel chain. The first part of the article presents a review of previous studies on the differentiation of the innovation activity in the hotel industry. The second part introduces the methodology of empirical research. The results are presented in the third part. The survey shows that the most innovative hotels in Poland are large and belong to international hotel chains.

Keywords: innovation, hotel enterprises, determinants of innovation activity. 


\section{Wstęp}

Przedsiębiorstwa hotelarskie w Polsce działają na coraz bardziej konkurencyjnym rynku, który podlega ciągłym zmianom ilościowym oraz jakościowym. Z jednej strony następuje wzrost liczby przedsiębiorstw oferujących usługi noclegowe, a $\mathrm{z}$ drugiej pojawiają się nowe modele działalności biznesowej (np. opierającej się na tzw. ekonomii współdzielenia), które stanowią wyzwanie dla tradycyjnie prowadzonych przedsiębiorstw hotelarskich. W tych okolicznościach jednym ze sposobów uzyskiwania i utrzymywania przewagi konkurencyjnej jest kreowanie nowych wartości dla klientów poprzez działalność innowacyjną. Mimo dużego znaczenia problematyki innowacji w hotelarstwie badania empiryczne stanowią wyjątkową rzadkość w tym sektorze [Hjalager 2010; Hall, Williams 2008].

$\mathrm{Z}$ dotychczasowych prac badawczych wynika, że przedsiębiorstwa hotelarskie są umiarkowanie innowacyjne [Sundbo i in. 2007]. Przy niezwykle dużym zróżnicowaniu podmiotów świadczących usługi hotelarskie trudno jest analizować ich innowacyjność bez wyodrębnienia bardziej jednorodnych grup. Poziom innowacyjności przedsiębiorstw może różnić się w zależności od wielkości, standardu czy przynależności do sieci hotelowej. Tego typu badania nie były jednak prowadzone w odniesieniu do przedsiębiorstw hotelarskich zlokalizowanych w Polsce. Dlatego za interesujące poznawczo uznano zbadanie poziomu innowacyjności hoteli w Polsce, a także czynników, które różnicują ten poziom.

\section{Zróżnicowanie innowacyjności przedsiębiorstw hotelarskich - przegląd badań}

Dotychczasowe badania prowadzone $\mathrm{w}$ hotelach nie rozstrzygają jednoznacznie wpływu wielkości przedsiębiorstw na ich innowacyjność [Orfila-Sintes, Mattsson 2009]. Hjalager [2002] wskazuje, że innowacyjność w hotelarstwie jest przede wszystkim domeną dużych podmiotów. Wpływ wielkości na innowacyjność można wyjaśniać pozytywnymi efektami skali, które ułatwiają podejmowanie działalności innowacyjnej [Becheikh i in. 2006]. Z drugiej strony wielkość przedsiębiorstwa może zmniejszać jego elastyczność i zdolność do szybkiego reagowania na rynkowe szanse i zagrożenia [Stock i in. 2002]. Tejada i Moreno [2013] wykazali, że wielkość hotelu, mierzona liczbą zatrudnionych pracowników, nie ma wpływu na innowacyjność hoteli. Z kolei wyniki badania Nievesa i Segarra-Ciprésa [2015] dowodzą istnienia tej zależności. Potwierdzają to także badania, które prowadzili López-Fernández, Serrano-Bedia i Gómez-López [2011] oraz Pikkemaat i Peters [2006]. Sundbo, Orfila-Sintes i Sørensen [2007] niższy poziom innowacyjności w małych obiektach tłumaczą rodzinnym charakterem tej działalności i naturalną tendencją do utrzymywania w nich status quo. Uwzględniając podejście do innowacji, Sørensen [2004] wyodrębnił dwa typy małych przedsiębiorstw hotelarskich: 
z jednej strony tradycyjne, rodzinne hotele o niskiej skłonności do innowacyjności, $\mathrm{z}$ drugiej - przedsiębiorcze i prężne przedsiębiorstwa nastawione na szybki rozwój, m.in. dzięki innowacjom.

Kolejnym czynnikiem, który może różnicować poziom innowacyjności, jest przynależność do sieci hotelowych. Z badań Sundbo i in. [2007] oraz López-Fernández, Serrano-Bedii i Gómez-Lópeza [2011] wynika, że hotele należące do sieci są bardziej innowacyjne niż obiekty niezależne. Sieć hotelowa stanowić może cenne źródło informacji wspomagające podejmowanie działalności innowacyjnej. Wiedza pochodząca $\mathrm{z}$ podmiotów tworzących sieci może być przekazywana $\mathrm{w}$ formie skodyfikowanej, np. podręczników, procedur, wytycznych, ale również w formie ukrytej, przykładowo w ramach szkoleń czy obserwacji. Pozytywny wpływ powiązań kooperacyjnych na innowacyjność w branży hotelarskiej wykazały badania prowadzone w Hiszpanii [Tejada, Moreno 2013]. Z drugiej strony przynależność do sieci może zmniejszać elastyczność przedsiębiorstwa poprzez konieczność dostosowania się do wymogów narzuconych przez centralę sieci i w efekcie ograniczać innowacyjność przedsiębiorstw sieciowych [Ottenbacher i in. 2006].

Jak wynika z dotychczasowych badań, istnieje także związek pomiędzy standardem hoteli a ich innowacyjnością. Orfila-Sintes, Crespi-Cladera i Martinez-Ros [2005] oraz Pikkemaat i Peters [2006] wykazali, że im wyższy standard hotelu mierzony liczbą gwiazdek, tym wyższa jego innowacyjność. Wysoki standard obiektu związany jest z dużą presją konkurencyjną i koniecznością dywersyfikowania oferty poprzez wdrażanie innowacji. Goście luksusowych hoteli oczekują bowiem zaskoczenia, nowych doznań oraz niestandardowego podejścia do procesu obsługi [Lai, Hitchoock 2017].

W kolejnej części artykułu przedstawiona została metodyka badania empirycznego poświęconego innowacyjności przedsiębiorstw hotelarskich w Polsce.

\section{Metodologia badania}

Badana populacja składała się z 2633 całorocznych obiektów hotelowych ${ }^{1}$. Badanie sondażowe obejmowało łącznie 400 hoteli $^{2}$, z podziałem na hotele należące do międzynarodowych sieci oraz na pozostałe. Podział populacji na dwie niezależne warstwy pozwolił na zastosowanie losowego i warstwowego doboru próby [Szreder 2010]. Badaniem objęto 326 hoteli niezależnych, działających poza strukturą międzynarodowych sieci hotelowych, i 74 hotele należące do takich sieci. W przypadku ostatniej kategorii dokonano tzw. nadreprezentacji danych, która oznaczała, że hotele sieciowe występowały w badanym podzbiorze liczniej, niż wynikało to

${ }^{1}$ Na podstawie Centralnego Wykazu Obiektów Hotelarskich. Stan wykazu aktualny na dzień 02.10.2015.

${ }^{2}$ Minimalna liczebność próby powinna wynosić 335 obiektów (poziom ufności 95\%, błąd maksymalny 5\%, wielkość frakcji 0,5). 
z informacji o całej populacji. Tym samym dobór miał charakter nieproporcjonalny [Szreder 2010].

Respondentami badania były osoby zarządzające hotelami lub wyznaczeni pracownicy szczebla kierowniczego. Operat badania stanowiła baza teleadresowa Centralnego Wykazu Obiektów Hotelarskich administrowana przez Ministerstwo Sportu i Turystyki. W każdym z hoteli zrealizowany został jeden wywiad techniką CAWI lub CATI. Największy odsetek w próbie hoteli niezależnych stanowiły małe (do 50 pokoi), trzygwiazdkowe obiekty. Z kolei wśród hoteli sieciowych najsilniejszym reprezentantem w próbie były obiekty czterogwiazdkowe, oferujące od 101 do 350 pokoi.

Rozmieszczenie hoteli objętych badaniem w podziale na województwa prezentuje rysunek 1.

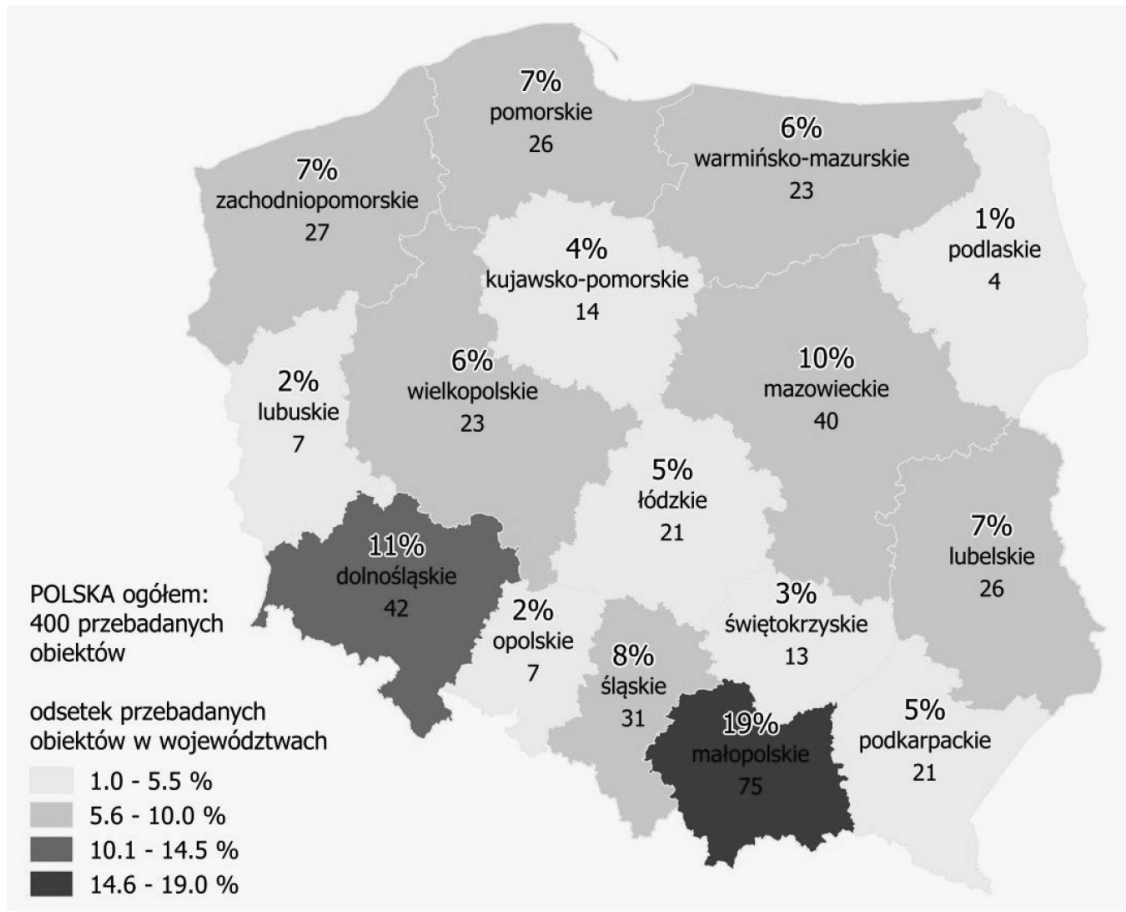

Rys. 1. Rozkład przestrzenny badanych obiektów

Źródło: opracowanie własne.

Z rozkładu geograficznego wynika, że największy odsetek przebadanych obiektów znajdował się w województwach małopolskim, dolnośląskim oraz mazowieckim. 


\section{Poziom innowacyjności i jego zróżnicowanie - wyniki badania}

Do pomiaru innowacyjności wykorzystano metodologię OECD [2005], uwzględniając innowacje produktowe, procesowe, organizacyjne i marketingowe. W celu porównania poziomu innowacyjności dokonana została kategoryzacja innowacyjności o jedno odchylenie standardowe, w wyniku której otrzymano sześciostopniową skalę: od bardzo niskiego do bardzo wysokiego poziomu innowacyjności. W grupie przedsiębiorstw objętych badaniem $57,2 \%$ charakteryzowało się niskim poziomem innowacyjności $(\mathrm{N}=229)$. Wyższą ocenę, oznaczającą raczej wysoki stopień innowacyjności, uzyskało co trzecie przedsiębiorstwo $(31,0 \%, \mathrm{~N}=124)$. Wysoki i bardzo wysoki poziom innowacyjności odnotowano łącznie dla 11,8\% badanych przedsiębiorstw $(\mathrm{N}=47)$. Ocena zróżnicowania innowacyjności przedsiębiorstw objęła następujące cechy: przynależność do międzynarodowej sieci hotelowej, kategorię hotelu (liczba gwiazdek) oraz wielkość hotelu (liczba posiadanych pokoi).

Analizując wyniki przedstawione w tabeli 1, należy stwierdzić, że wyższym indeksem innowacyjności odznaczają się hotele przynależące do międzynarodowych sieci hotelowych niż obiekty niebędące członkiem takich sieci.

Tabela 1. Poziom innowacyjności przedsiębiorstw ze względu na przynależność do sieci

\begin{tabular}{|l|c|c|c|c|}
\hline \multirow{2}{*}{ Poziom innowacyjności } & \multicolumn{4}{|c|}{ Rodzaj obiektu } \\
\cline { 2 - 5 } & niezależne & sieciowe & niezależne & sieciowe \\
\cline { 2 - 5 } & $\mathrm{N}=326$ & $\mathrm{~N}=\mathbf{7 3}$ & $100,0 \%$ & $100,0 \%$ \\
\hline bardzo niski & 0 & 0 & $0,0 \%$ & $0,0 \%$ \\
\hline niski & 44 & 2 & $\mathbf{1 3 , 5 \%}$ & $2,7 \%$ \\
\hline raczej niski & 154 & 29 & $\mathbf{4 7 , 2 \%}$ & $39,7 \%$ \\
\hline raczej wysoki & 99 & 25 & $30,4 \%$ & $\mathbf{3 4 , 2 \%}$ \\
\hline wysoki & 15 & 10 & $4,6 \%$ & $\mathbf{1 3 , 7 \%}$ \\
\hline bardzo wysoki & 14 & 7 & $4,3 \%$ & $\mathbf{9 , 6 \%}$ \\
\hline
\end{tabular}

$*$ brak danych $=1$.

Źródło: opracowanie własne na podstawie wyników badania ilościowego.

Poziom innowacyjności badanych przedsiębiorstw wzrasta wraz ze standardem hoteli mierzonym liczbą gwiazdek, tym samym: im wyższy standard, tym wyższy stopień ich innowacyjności. Wyjątkiem są obiekty o niższej kategorii, posiadające od jednej do trzech gwiazdek, które charakteryzuje równie bardzo wysoka innowacyjność, jak w przypadku obiektów o największej liczbie gwiazdek w Polsce (por. tab. 2).

Podobną tendencję można zaobserwować, analizując poziom innowacyjności w podziale na wielkość przedsiębiorstwa (mierzoną za pomocą liczby oferowanych pokoi): im większy obiekt hotelarski, tym wyższy stopień innowacyjności. Bardzo 
Tabela 2. Poziom innowacyjności przedsiębiorstw ze względu na kategorię obiektu

\begin{tabular}{|l|c|c|c|c|c|c|}
\hline \multirow{2}{*}{ Poziom innowacyjności } & \multicolumn{7}{|c|}{ Kategoria obiektu } \\
\cline { 2 - 7 } & $\begin{array}{c}* * * \\
\text { lub mniej }\end{array}$ & $* * * *$ & $* * * * *$ & $\begin{array}{c}* * * \\
\text { lub mniej }\end{array}$ & $* * * *$ & $* * * * *$ \\
\cline { 2 - 7 } & $\mathrm{N}=265$ & $\mathrm{~N}=98$ & $\mathrm{~N}=37$ & $100,0 \%$ & $100,0 \%$ & $100,0 \%$ \\
\hline bardzo niski & 0 & 0 & 0 & $0,0 \%$ & $0,0 \%$ & $0,0 \%$ \\
\hline niski & 38 & 7 & 1 & $14,3 \%$ & $7,1 \%$ & $2,7 \%$ \\
\hline raczej niski & 123 & 44 & 16 & $\mathbf{4 6 , 4 \%}$ & $44,9 \%$ & $43,2 \%$ \\
\hline raczej wysoki & 72 & 38 & 14 & $27,2 \%$ & $38,8 \%$ & $37,8 \%$ \\
\hline wysoki & 15 & 7 & 4 & $5,7 \%$ & $7,1 \%$ & $10,8 \%$ \\
\hline bardzo wysoki & 17 & 2 & 2 & $\mathbf{6 , 4 \%}$ & $2,0 \%$ & $5,4 \%$ \\
\hline
\end{tabular}

Źródło: opracowanie własne na podstawie wyników badania ilościowego.

wysoka innowacyjność charakteryzuje zarówno obiekty mniejsze (poniżej 50 pokoi), jak i większe (powyżej 101 pokoi). Jednak większe hotele okazywały się bardziej innowacyjne niż pozostałe, o czym świadczy dużo mniejszy odsetek obiektów osiągających niski i raczej niski poziom innowacyjności w tej grupie analizowanych przedsiębiorstw (por. tab. 3).

Tabela 3. Poziom innowacyjności przedsiębiorstw ze względu na wielkość

\begin{tabular}{|l|c|c|c|c|c|c|}
\hline \multirow{2}{*}{ Poziom innowacyjności } & \multicolumn{7}{|c|}{ Liczba pokoi } \\
\cline { 2 - 7 } & $\begin{array}{c}50 \\
\text { lub mniej }\end{array}$ & $51-100$ & $\begin{array}{c}101 \\
\text { lub więcej }\end{array}$ & $\begin{array}{c}50 \\
\text { lub mniej }\end{array}$ & $51-100$ & $\begin{array}{c}101 \\
\text { lub więcej }\end{array}$ \\
\cline { 2 - 7 } & $\mathrm{N}=223$ & $\mathrm{~N}=93$ & $\mathrm{~N}=84$ & $100,0 \%$ & $100,0 \%$ & $100,0 \%$ \\
\hline bardzo niski & 0 & 0 & 0 & $0,0 \%$ & $0,0 \%$ & $0,0 \%$ \\
\hline niski & 32 & 10 & 4 & $\mathbf{1 4 , 3 \%}$ & $10,8 \%$ & $4,8 \%$ \\
\hline raczej niski & 104 & 48 & 31 & $46,6 \%$ & $\mathbf{5 1 , 6 \%}$ & $36,9 \%$ \\
\hline raczej wysoki & 60 & 29 & 35 & $26,9 \%$ & $31,2 \%$ & $\mathbf{4 1 , 7 \%}$ \\
\hline wysoki & 12 & 5 & 9 & $5,4 \%$ & $5,4 \%$ & $\mathbf{1 0 , 7 \%}$ \\
\hline bardzo wysoki & 15 & 1 & 5 & $\mathbf{6 , 7 \%}$ & $1,1 \%$ & $6,0 \%$ \\
\hline
\end{tabular}

Źródło: opracowanie własne na podstawie wyników badania ilościowego.

W celu zbadania związku między zmiennymi: sieciowość hotelu, standard i wielkość, przeprowadzono testy niezależności chi-kwadrat (por. tab. 4).

Weryfikacji poddano przypuszczenie o występowaniu różnic analizowanych rozkładów zmiennych. Hipoteza zerowa zakładała brak związku oznaczający, że każda z wymienionych zmiennych nie miała wpływu na poziom innowacyjności badanych przedsiębiorstw. Przeprowadzone testy niezależności chi-kwadrat wskazują, że rozkłady zmiennej innowacyjność różnią się istotnie pod względem sieciowości 
Tabela 4. Testy niezależności chi-kwadrat dla zmiennych: sieć, kategoria, liczba pokoi

\begin{tabular}{|l|c|c|c|c|l|}
\hline \multicolumn{1}{|c|}{ zmienne } & $\chi^{2}$ otrzymane & $\begin{array}{c}\text { stopnie } \\
\text { swobody }(\mathrm{df})\end{array}$ & $\begin{array}{c}\chi^{2} \text { krytycze } \\
(\mathrm{p}=0,05)\end{array}$ & \multicolumn{2}{|c|}{ wynik } \\
\hline sieć & 18,06448 & 5 & 11,0708 & $\chi^{2}{ }_{\text {otrzymane }}>\chi^{2}{ }_{\text {krytyczne }}$ & $\begin{array}{l}\text { odrzucenie } \\
\text { hipotezy } \\
\text { zerowej }\end{array}$ \\
\hline kategoria & 13,79821 & 10 & 18,307 & $\chi^{2}{ }_{\text {otrzymane }}<\chi^{2}{ }_{\text {krytyczne }}$ & $\begin{array}{l}\text { przyjęcie } \\
\text { hipotezy } \\
\text { zerowej }\end{array}$ \\
\hline wielkość & 18,39715 & 10 & 18,307 & $\chi^{2}$ otrzymane $^{>} \chi^{2}{ }_{\text {krytyczne }}$ & $\begin{array}{l}\text { odrzucenie } \\
\text { hipotezy } \\
\text { zerowej }\end{array}$ \\
\hline
\end{tabular}

* Poziom istotności: $\mathrm{p}=0,05 ; \mathrm{H}_{0}$ : brak związku (zmienne nie różnicują innowacyjności); $\mathrm{H}_{1}$ : istnieje związek (zmienne różnicują innowacyjność).

Źródło: opracowanie własne na podstawie wyników badania ilościowego.

oraz wielkości obiektów. Nie różnią się natomiast dla obiektów porównywanych pod względem standardu (kategoria obiektu), o czym świadczy przyjęcie hipotezy zerowej, opisującej brak związku dla tej zależności.

\section{Zakończenie}

Analiza wyników wskazuje, że polskie hotele podejmują działania mające na celu tworzenie innowacji, jednak ogólny poziom ich innowacyjności jest umiarkowany. Najczęstszym wynikiem działalności innowacyjnej są nowe lub znaczące zmiany w ofercie, metodach świadczenia usług oraz promocji i marketingu. Są to obszary, które w największym stopniu decydują o konkurencyjności i pozwalają na wyróżnienie oferty przedsiębiorstwa na rynku.

Innowacyjność badanych obiektów zależy przede wszystkim od przynależności do międzynarodowych sieci hotelarskich oraz wielkości obiektu (istotność statystyczna). Uzyskane wyniki są częściowo zgodne z dotychczasowymi pracami badawczymi innych autorów zajmujących się tematyką innowacji w sektorze hotelarskim. Potwierdziły się wnioski płynące z badań: Sørensena [2004], López-Fernándeza, Serrano-Bedia i Gómez-López [2011] oraz Nieves i Segarra-Ciprés [2015] wskazujące, że wielkość przedsiębiorstw ma pozytywne znaczenie dla innowacyjności przedsiębiorstw hotelarskich, a także prac Sundbo i in. [2007] dotyczących hoteli sieciowych. Zarówno wielkość przedsiębiorstwa, jak i przynależność do sieci związana jest z dostępem do zasobów. Duże, sieciowe przedsiębiorstwa mają większe możliwości wykorzystania infrastruktury i bardziej wykwalifikowanych zasobów ludzkich, a dzięki temu mogą mieć większą zdolność do absorpcji wiedzy, która jest źródłem innowacji. Jak wskazują Nieves i Segarra-Ciprés [2015], zdolność 
przedsiębiorstw hotelarskich do tworzenia innowacji w dużym stopniu związana jest z jakością zasobów ludzkich. Duże, międzynarodowe przedsiębiorstwa dysponują także większymi możliwościami finansowania działalności innowacyjnej, zarówno z własnych, jak i zewnętrznych źródeł. W tego typu przedsiębiorstwach zachodzi również profesjonalizacja i specjalizacja działalności. W większym zakresie wykorzystywane są ponadto nowe technologie i metody zarządzania [Sundbo i in. 2007]. Badanie zlokalizowanych w Hiszpanii sieci hotelowych dowodzi, że zdecydowana większość z nich posiada nawet własne działy badawczo-rozwojowe (R\&D), których celem jest tworzenie i wdrażanie innowacji [Vila i in. 2012].

Wyniki badania dowodzą, że najwyższy poziom innowacyjności charakteryzuje duże obiekty, o najwyższym standardzie. Jednak pogłębiona analiza wykazała, że istnieje porównywalny na tym poziomie innowacyjności odsetek małych hoteli (dysponujących co najwyżej 50 pokojami) o niższym standardzie (co najwyżej trzech gwiazdek). Na tej podstawie można wnioskować, że innowacyjność nie musi być domeną tylko dużych hoteli, które dysponują większymi zasobami finansowymi i organizacyjnymi. Zjawisko to wythumaczyć można, odwołując się do teorii zasobowej, a szczególnie do koncepcji dźwigni zasobowej. Hamel i Prahalad [1993] twierdzą, że możliwe jest uzyskiwanie lepszych efektów z mniejszej ilości zasobów. W mniejszych obiektach wyższą produktywność posiadanych zasobów udaje się uzyskać z jednej strony dzięki ambicji i zaangażowaniu, a z drugiej poprzez efektywniejszą koncentrację zasobów na kluczowych celach [Haffer 2003].

Podsumowując, należy stwierdzić, że wzrost poziomu innowacyjności hoteli w Polsce następować może poprzez podejmowanie działań kooperacyjnych, pozwalających na uzyskanie dostępu do zasobów znajdujących się w dyspozycji innych podmiotów. W tym celu warto nawiązywać współpracę, np. w ramach niezależnych zrzeszeń hoteli, która pozwoli na dostęp do zasobów przy jednoczesnym niewielkim ograniczeniu samodzielności i elastyczności działania. Dalsze prace badawcze powinny koncentrować się na wewnętrznych i zewnętrznych źródłach innowacyjności przedsiębiorstw hotelarskich w Polsce oraz na czynnikach determinujących innowacyjność tego sektora, gdyż jest to zagadnienie istotne i nadal niedostatecznie zbadane.

\section{Literatura}

Becheikh N., Landry R., Amara N., 2006, Lessons from innovation empirical studies in the manufacturing sector: A systematic review of the literature from 1993-2003, Technovation, vol. 26, no. 5-6, s. 644-664.

Haffer R., 2003, Systemy zarzadzania jakościa w budowaniu przewag konkurencyjnych przedsiębiorstw, Wydawnictwo Naukowe UMK, Toruń.

Hall C.M., Williams A.M., 2008, Tourism and innovation, Routledge, London.

Hamel G., Prahalad C.K., 1993, Strategy as stretch and leverage, Harvard Business Review, vol. 71, no. 2 , s. $75-84$. 
Hjaalger A.M., 2002, Repairing innovation defectiveness in tourism, Tourism Management, vol. 23, no. 5, s. 465-474.

Hjalager A., 2010, A review of innovation research in tourism, Tourism Management, vol. 31, no. 1, s. $1-12$.

Lai I.K.W., Hitchcock M., 2017, Sources of satisfaction with luxury hotels for new, repeat, and frequent travelers: A PLS impact-asymmetry analysis, Tourism Management, vol. 60, s. 107-129.

López-Fernández M.C., Serrano-Bedia A.M., Gómez-López R., 2011, Factors Encouraging Innovation in Spanish Hospitality Firms, Cornell Hospitality Quarterly, vol. 52, no. 2, s. 144-152.

Nieves J., Segarra-Ciprés M., 2015, Management innovation in the hotel industry, Tourism Management, vol. 46, s. 51-58.

OECD, 2005, Oslo Manual. The Measurement of Scientific and Technological Activities. Guidelines for collecting and interpreting innovation data, Third edition, Brussels.

Orfila-Sintes F., Crespi-Cladera R., Martinez-Ros E., 2005, Innovation activity in the hotel industry: evidence from Balearic Islands, Tourism Management, vol. 26, no. 6, s. 851-865.

Orfila-Sintes F., Mattsson J., 2009, Innovation behavior in the hotel industry, Omega, vol. 37, no. 2, s. 380-394.

Ottenbacher M., Shaw V., Lockwood, A., 2006, An Investigation of the Factors Affecting Innovation Performance in Chain and Independent Hotels, Journal of Quality Assurance in Hospitality \& Tourism, vol. 6, no. 3-4, s. 113-128.

Pikkemaat B., Peters M., 2006, Towards the Measurement of Innovation - A Pilot Study in the Small and Medium Sized Hotel Industry, Journal of Quality Assurance in Hospitality \& Tourism, vol. 6, no. 3-4, s. 89-112.

Shaw G., Williams A.M., 2009, Knowledge transfer and management in tourism organisations: An emerging research agenda, Tourism Management, vol. 30, no. 3, s. 325-335.

Sørensen F., 2004, Tourism Experience Innovation Networks: Tourism Experience Innovations and the Role of Geographically Organised Production and Information Innovation Networks, Roskilde Universitet, Roskilde.

Stock G.N., Greis N.P., Fischer W.A., 2002, Firm size and dynamic technological innovation, Technovation, vol. 22 , no. 9, s. $537-549$.

Sundbo J., Orfila-Sintes F., Sørensen F., 2007, The innovative behavior of tourism firms - Comparative studies of Denmark and Spain, Research Policy, vol. 36, no. 1, s. 88-106.

Szreder M., 2010, Metody i techniki sondażowych badań opinii, PWE, Warszawa.

Tejada P., Moreno P., 2013, Patterns of innovation in tourism 'Small and Medium-size Enterprises', The Service Industries Journal, vol. 33, no. 7-8, s. 749-758.

Vila M., Enz C., Costa G., 2012, Innovative Practices in the Spanish Hotel Industry, Cornell Hospitality Quarterly, vol. 53, no. 1, s. 75-85. 